\title{
GENETICS AND INHERITANCE OF SEED DORMANCY INFLICTED BY SEED- COAT FACTORS IN RICE (ORYZA SATIVA L.)
}

\author{
ZL Kanyeka \\ Department of Botany, University of Dar es Salaam P.O. Box 35060, \\ Dar es Salaam. Tanzania. kanyeka@,botany.udsm.ac.tz/ \\ zkanyeka@yahoo.com
}

\begin{abstract}
The study was undertaken to investigate the genetic mode of inheritance of dormancy imposed by the hull (seed coat) in rice seeds. Freshly harvested seeds of parents, $F_{1}$ and $F_{2}$ populations of a cross between a dormant cultivar Kisegese and non-dormant strain K2004 were used. Germination test of the de-hulled (without seed coat) and un-dehulled (whole or with seed coat) seeds were conducted at 10 days intervals starting at 15 days after harvesting (15DAH) for 65 days. The seeds were sown in petri dishes. Numbers of germinated and un-germinated seeds were recorded at 7 days after sowing. Germination of seeds with seed coat (unhulled) of the dormant Kisegese was less than 65\% even at 65DAH where as its dehulled seeds (without seed coats) showed more than $90 \%$ of germination at 15DAH, indicating that dormancy was imposed by the seed hull. The dormancy was also found to be controlled by dominant genes when an $F_{1}$ undehulled seeds were dormant at 35DAH and the dehulled seeds were non-dormant. The $F_{2}$ population ratio indicated that seed coat-imposed dormancy in the rice cultivar Kisegese was controlled by two complementary dominant genes.
\end{abstract}

\section{INTRODUCTION}

The longevity of seed viability of domestic crops is a function of genotype, dormancy and storage conditions. Mature plant seeds can be viable before or at their separation from the mother plants, but may not be capable of immediate germination due to dormancy factors. Dormancy is the temporary arrest of seed development before completion of their maturation process. It is a condition during which the growth and development of rice seeds is temporarily suspended and it occurs in the formation period of seeds and continues for certain period of time (Takahashi 1962, Gardner et al. 1985). According to Sheshu and Sorrells (1986), seed dormancy in rice is attributed to both the embryo and seed coat factors (hull factors). Several workers have reported mode and inheritance pattern of seed dormancy imposed by combined factors of the hull and embryo in rice (Tomar 1984, Das 1985, Takahashi 1997). However, few attempts have been made to analyze the inheritance of seed dormancy imposed separately by its components (i.e. factors contributed by embryo and seed coat (hull) of the rice seeds (Shenoy 2004). In view of this knowledge gap, the present study was undertaken to investigate the genetic mode of inheritance of dormancy imposed by seed coat factors in rice seeds using $F_{1}$ and $F_{2}$ populations data of a cross between a dormant and non-dormant rice genotypes.

\section{MATERIALS AND METHODS}

The experiment was conducted in the greenhouse of the Botany Department of the University of Dar es Salaam in 2001 to 2003. It was part of the hybridization project of incorporating genes of resistance to RYMV in local rice cultivars. Seeds from one of the crosses made between cultivar Kisegese and local strain K2004 were used for this study. Seeds of the former show strong dormancy whereas seeds of K2004 are non- dormant. The freshly harvested seeds from $F_{1}$ and $F_{2}$ populations were used to assess the dormancy through germination for two months (65 days) after harvesting. For each seed lot $\left(\mathrm{F}_{1}, \mathrm{~F}_{2}\right.$ and parents $)$ two sets of seeds were sown in petri dishes; (i) 
seeds with seed-coats (unhulled) and (ii) seeds without seed coat (dehulled). In each petri dish, 25 seeds arranged in five rows were sown. The seeds were planted at every 10 days-intervals after harvesting starting at 15DAH for 65 days (Table 1).

Table 1: $\quad$ Seed germination trends of dormant and non-dormant cultivars

\begin{tabular}{llllllll}
\hline Cultivar & Condition & \multicolumn{7}{c}{ Germination \%ays after harvesting } \\
& & 15 & 25 & 35 & 45 & 55 & 65 \\
\hline $\begin{array}{l}\text { Kisegese } \\
\text { (Dormant) }\end{array}$ & Without seed coat & 92 & 96 & 100 & 99 & & \\
& With seed coat & 9 & 15 & 29 & 56 & 64 & 69 \\
K2004 & Without seed coat & 69 & 92 & 100 & 100 & & \\
(Non-dormant) & & & & & & & \\
& With seed coat & 74 & 84 & 95 & 97 & 96 & 98 \\
F $_{1}$ seeds & With seed coat & & 84 & 88 & 87 & & \\
& Without seed coat & & 34 & 42 & 56 & & \\
\hline
\end{tabular}

The seeds were sown in petri dishes lined with mesh cloth and watered twice per day using distilled water. The number of germinated and un-germinated seeds was recorded at seven and/or eight days after sowing and the data used to calculate the percentage of the seed lots using the formula; $\%$ Germination $=($ Germinated seeds / Total number of seed) x 100 . Similarly, to estimate the proportion of dormant to non-dormant plants in the $F_{2}$, germination tests were conducted using seeds with seed-coat (unhulled) harvested from 250 single plants raised in $20 \mathrm{~L}$. capacity plastic pots. The $\mathrm{F}_{2}$ seeds were stored for 25 days after harvesting (25DAH). The germination of all seed lots were tested at more than $26^{\circ} \mathrm{C}$ for 8 days

\section{RESULTS AND DISCUSSION}

Table 1, shows seed germination patterns of dormant (Kisegese), non-dormant (K2004) rice cultivars and their $F_{1}$ plants. Whole seeds (un-dehulled) and seeds without seedcoats (dehulled) of the non-dormant local strain K-2004 showed more than $90 \%$ of germination at 25 days after harvesting (25DAH). The germination of seeds with seed coats of the dormant parent Kisegese was not higher than $65 \%$ even after $65 \mathrm{DAH}$, while its seeds without the seed-coats (dehulled) exhibited more than $90 \%$ of germination at $15 \mathrm{DAH}$, indicating that the dormancy is imposed by the seed coat factors.

\section{$F_{1}$ seeds from hybrid plants}

$F_{1}$ seeds without seed coats (dehulled) were non-dormant while the $F_{1}$ with seeds coats were dormant at $35 \mathrm{DAH}$. This indicates that the dormancy is a dominant trait. In this study, seed lots with more than $80 \%$ germination were regarded as nondorminant. The seed lots of dehulled seeds of the parents and the $\mathrm{F}_{1}$ plants at $35 \mathrm{DAH}$ showed no dormancy, while seeds with seed coats (with hulls) of the dormant parent and $\mathrm{F}_{1}$ revealed dormancy. This suggests that dormancy at $35 \mathrm{DAH}$ was caused by the seed-coat factors only (Table 1).

\section{Estimation of $F_{2}$ population ratios}

To estimate the ratio of dormant to nondormant plants in $F_{2}$ populations, germination test was done with seeds possessing the seed coats (undehulled) after 35 days after harvesting (35DAH). The 250 $\mathrm{F}_{2}$ plants evaluated for germination at 
35DAH with seed coats, 143 plants were dormant and 107 plants were non dormant. Strictly speaking, seeds from $F_{2}$ plants represent $\mathrm{F}_{3}$ generation, but the seed coats (hulls) belong to the mother plants and its genotype is identical to $F_{2}$ plants (Shenoy 2004). The proportion of $F_{2}$ plants was assumed to be $9: 7$ indicating a good fit with the observed ratio (Table 2).

Table 2: $\quad$ Segregation of seed dormancy in an F2 population from a cross between cultivars Kisegese and K2004

\begin{tabular}{llllll}
\hline \multirow{2}{*}{ Class } & \multicolumn{2}{c}{ Number of Seeds } & Total & $\mathbf{X}^{\mathbf{2}}$ & Probability \\
\cline { 2 - 4 } & Dormant & $\begin{array}{c}\text { Non }- \\
\text { dormant }\end{array}$ & & & \\
\hline $\begin{array}{l}\text { Observed } \\
\begin{array}{l}\text { Expected } \\
(9: 7)\end{array}\end{array}$ & 143 & 107 & 250 & 0.092 & $\begin{array}{l}0.90-0.75 \\
(\mathrm{df}=1)\end{array}$ \\
\hline
\end{tabular}

\section{ACKNOWLEDGEMENTS}

The Faculty of Science (core) support funds of Sisa/SAREC is highly appreciated for meeting the management costs of this project.

\section{REFERENCES}

Das RC 1985 Role of a hull in inheritance of dormancy in rice. Exptl. Genetics 1 (2): 119-125.

Gardner FP, Pearce RB and R Mitchell 1985 Physiology of crop planst. $1^{\text {st }}$ Ed Iowa State University Press Ames

Sheno VV 2004 Genetics of hull-imposed dormancy in rice.

http://grain.jouy.inra.fr/ggpages/rgn/r gn10/vXIV28.htm
Sheshu DV and Sorrell K 1986 Genetic studies on seed dormancy in rice. IRRI (Ed) Rice Genetics. Pp.269-382.

Takahashi T 1997 Phsio-genetic studies on germination of rice seeds with special reference to its genetic factors. Bull. Inst. Res. Tohoku University 14:1$879(\mathrm{~J})$.

Takahashi T 1997 Inheritance of seed germination and dormancy. In Science of the Rice Plant Genetics. Vol. 3. Eds. T Matsao et al (1997). FAO Policy Center, Tokyo.

Tomar JB 1984 Genetics of grain dormancy in rice (Oryza sativa L.) Genetica Algeria: 38 (4:)443-446. 